\title{
Key problems in organizing and structuring university research in Vietnam: the lack of an effective research "behaviour formalization" system
}

\author{
TL Huong Nguyen* \\ Doctor \\ Swinburne Business School, Swinburne University of Technology \\ PO Box 218, Mail H25, Hawthorn, VIC 3122, Australia \\ Phone: + 61424525699 \\ Email: huongnguyen@swin.edu.au
}

\author{
Vincent Lynn Meek \\ Professor \\ The University of Melbourne \\ Parkville \\ VIC 3010, Australia \\ vmeek@unimelb.edu.au
}

*Corresponding author

\section{Introduction}

In terms of 'economies which are directly based on the production, distribution and use of knowledge and information' (OECD 1996), a country with a powerful research and innovation system can gain a competitive edge in the global market, which can serve as a strong basis for economic and social development (Meek and Davies 2009). However, building university research capacity in developing countries can be a tremendously difficult process (Altbach 2007; Salmi 2009). While research has taken firm root in higher education for centuries in industrialized countries, in many developing countries, research often remains an unfamiliar activity. Universities in developing nations often lack the most basic conditions for doing research such as human resources, infrastructure and funding, and a favourable policy environment (Nguyen 2013a). If less developed countries continue to neglect building research and innovation capacity, they will lag well behind other industrialized nations not only in science and economics but also in social development.

To help universities in developing countries improve their research capacity, we need to gain further understanding of their capacity-building needs. However, it appears that such knowledge is lacking. The body of work on university research management is rather Western-biased with publications mostly focussing on such contexts as the USA (Thoenig and Paradeise 2014), Australia (Bazeley 2010), New Zealand (Edgar and Geare 2013), and the UK (Taylor 2006; Taylor 2011). Thanks to a recent movement of establishing research universities worldwide (Marginson 2014) and some wellknown international organizations' renewed attention to research and innovation capacity building in developing countries (WorldBank 1998/99; UN Millennium Project 2003), there seems to be more research on university research capacity building in economically disadvantaged contexts (Altbach and Balán 2007; Liu et al. 2011; Altbach and Salmi 2011; Olsson and Meek 2013). However, relevant studies are still very limited. There are few empirical publications on university research capacity building in Vietnam either in Vietnamese or English (Nguyen 2015).

To extend the discussion on university research capacity building in developing countries, this paper presents partial findings from a study that examines the prospects, challenges and possibilities that four leading Vietnamese universities experienced in building and enhancing research capacity 
(Nguyen 2014). The overall research project examines five aspects of university research capacity building: research resources (Nguyen 2013a), research structural organization (Nguyen and Meek 2015), research related human resources policies (Nguyen 2015), research management plans, and research cultures. This paper investigates issues related to the second component of this five-element research capacity building framework. More specifically, through document analysis and semistructure interviews with 55 university participants, the study examines (1) the current research organizational structure of the four leading Vietnamese universities, (2) these university leaders', managers', and academics' perceptions of the effectiveness of their current structures and (3) suggestions on how the structures can be improved to best support research. This topic is very important because structure seems to be at the root of many of the questions raised about organizational effectiveness (Mintzberg 1979).

This study contributes significantly to the literature on university research management. University research management is generally described as "uncharted territory" (Edgar and Geare 2013), an area "largely unexplored" and a "modestly known" research topic (Bosch and Taylor 2011) with very scant attention being paid to developing countries. By providing an exploratory empirical account on the problems associated with the structure and organization of university research in Vietnam, firstly, this study helps to redress the imbalance in research on university research management between developed and developing contexts. Secondly, through identifying the management gaps and suggesting relevant strategies for enhancing structuring and organizing research at the four leading Vietnamese universities, this study provides practical knowledge in devising appropriate strategies for research development. This information is useful not only for the four specific Vietnamese universities but also for other universities within a similar development context.

The paper is structured as follows: after this brief introduction, a background to the study is presented in two parts: (1) an overview of the science and technology system in Vietnam and the context of Vietnamese university research and (2) key considerations in organizing and structuring university research. Then, the research questions and the research methods of the study are stated. Next, the paper presents the findings on research organizational structure of four leading Vietnamese universities and discusses major problems associated with it. Finally, the study concludes with recommendations for what organizational and structural strategies should be developed to enhance university research capacity building in Vietnam.

\section{Background}

\section{An Overview of the Science and Technology System in Vietnam}

Figure 1 represents the organizational structure of the science and technology system in Vietnam. As one of the world's five remaining single-party socialist states espousing communism (along with China, Cuba, Laos, and North Korea), in Vietnam, the Soviet model of research organizational structure (Berg 1995) still prevails. Research is still mainly undertaken in centrally funded and controlled research institutes outside universities.

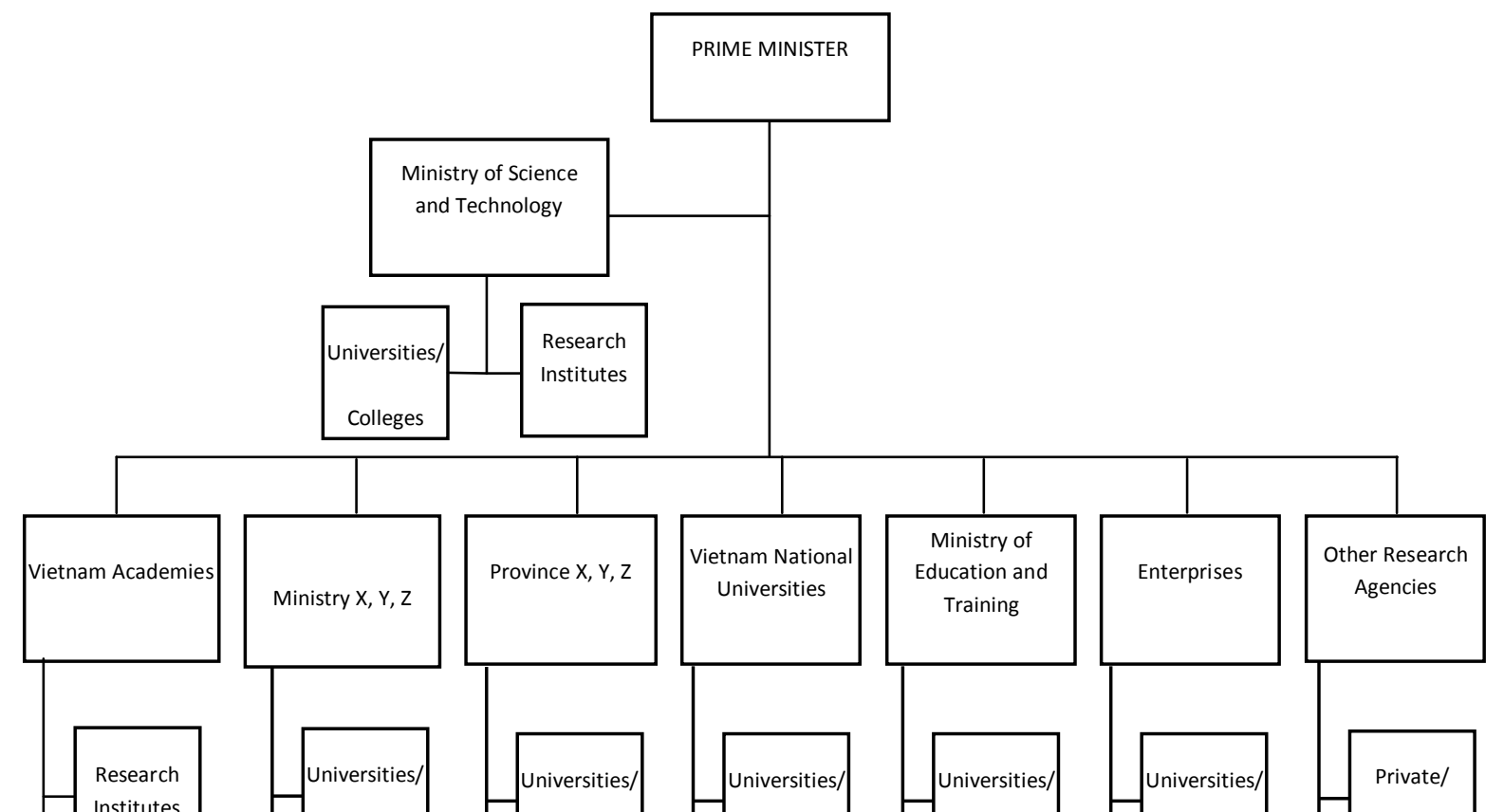


Fig 1 Organizational structure of the science and technology system in Vietnam (Nguyễn 2014)

At the national level, two Vietnam Academies report directly to the Prime Minister: the Vietnam Academy of Social Sciences and the Vietnamese Academy of Science and Technology. At the ministry level, each ministry often has a number of research institutes that do research to inform policy-making for that particular portfolio. At the provincial level, each province also has a number of research institutes undertaking research needed for provincial development. As of 2013, Vietnam has over 1,600 R\&D organizations (T.T.H. Tran, personal communication, 9 April 2013, as cited in Nguyễn 2014). Businesses own a very small number of R\&D centres, only 5.3\% of the total number of research organizations. Research institutes and centres from Vietnamese universities constitute just $11.1 \%$ of the total number of research organizations (Ca and Hung 2010).

Although research has been historically undertaken mainly through research institutes, since implementing the 'doi moi' (all-round renovation) policy ${ }^{1}$ in 1986, the Vietnamese government has encouraged universities to develop their research capacity. By the academic year 2012-2013, Vietnam had a total of 207 universities and 214 colleges (Bộ giáo dục và đào tạo 2013). These higher education institutions enrol a total number of 1,453,067 and 724,232 students, respectively. Since 2004, the government has identified a group of 16 key universities (Chính phủ 2004). These include two national and three regional universities and 11 normal universities specializing in various disciplines such as teacher education, medical sciences, economics, agriculture and forestry, technology, and the military forces. These key universities are generally expected to become leading institutions in Vietnam, especially in research.

Since 2006, Vietnam also planned to establish four, new, world-class public universities with support and sponsorship from the more developed countries. The Vietnamese-German University (established in 2008) and the University of Science and Technology of Hanoi in partnership with the French government (established in 2009) are already operating. In 2011, a memorandum on the establishment of Vietnam-Russia University of Technology in Hanoi was signed. In 2014, The Vietnamese Japanese university was established (Thủ tướng Chính phủ 2014b). These universities are expected to be "a new model, of high quality, and quickly reaching international standards" (Trần Thị Hà, as cited in Ha 2009). In 2014, the government of Vietnam also approved in principle the establishment of Fulbright University Vietnam as the country's first private, non-profit institution of higher education (Thu tướng Chính phủ 2014a). Vietnam planned to have 20 universities with at least an internationally recognized teaching program each by the year 2015. The country also aims to have at least one Vietnamese university to be ranked in the world's top 200 universities by the year 2020 (Thủ tướng chính phủ 2007).

Despite having developed a basic legal structure for managing the science and technology portfolio (Ly 2013) and having a great desire to improve university research capacity, a close examination of the Vietnamese university research policy environment reveals that there seem to be almost no

1 The key characteristic of this policy is the transition from a centralized planned economy heavily based on imports to a market-oriented one. 
powerful and/or special strategies, policies, and processes in place to enhance university research in Vietnam (Nguyễn 2014). Vietnamese universities have limited research capacity, low research productivity, and produce poorly utilized and irrelevant research (Hien 2010; Nguyen and Pham 2011; Nguyễn 2014).

In this context, deep insights about the efficiency and effectiveness of university research management processes and strategies are needed so that appropriate solutions for enhancing their institutional research capacity and performance can be devised. However, there seems to be very little systematic investigation of such issues in either Vietnamese or English language publications. Apart from Nguyen (2013a, 2015), who investigate the research resources management challenges at four leading Vietnamese universities, almost no empirical research has been published on these matters in Vietnam. By examining the prospects and problems associated with organizing and structuring research tasks, this study adds insight into university research capacity building and management in Vietnam. The next section examines key considerations in organizing and structuring university research.

\section{Key Considerations in Organizing and Structuring University Research}

Organizing and structuring research is a key task in university research management. Organizational structure is defined as:

the typically hierarchical arrangement of lines of authority, communications, rights and duties of an organization; it determines how the roles, power and responsibilities are assigned, controlled, and coordinated, and how information flows between the different levels of management. How an organization is structured depends on its objectives and strategy. (BusinessDictionary.com, para 1-2)

Based on Mintzberg's (1979) theory on the structuring of organization and other research management studies, Nguyen and Meek (2015) identified ten generic parameters of organizing and structuring research and explored how these ten proposed rules of organization are applied at the Group of Eight universities in Australia (see Figure 1). Drawing on this study, this section discusses these major considerations. Together these are used as a conceptual framework to analyze the research structure and organization of four leading Vietnamese universities. Figure 1 summarizes these 10 elements. Five are more visible and five are less tangible. The following section describes these categories in further detail.

\section{The Five More Visible Elements}

The five more visible parameters consist of: (1) create research positions; (2) create research management positions; (3) decide primary organizational units for research delivery; (4) create a research office; and (5) create research oversight committees. These parameters are considered to be more visible because some specific positions involving people are the end products of these actions.
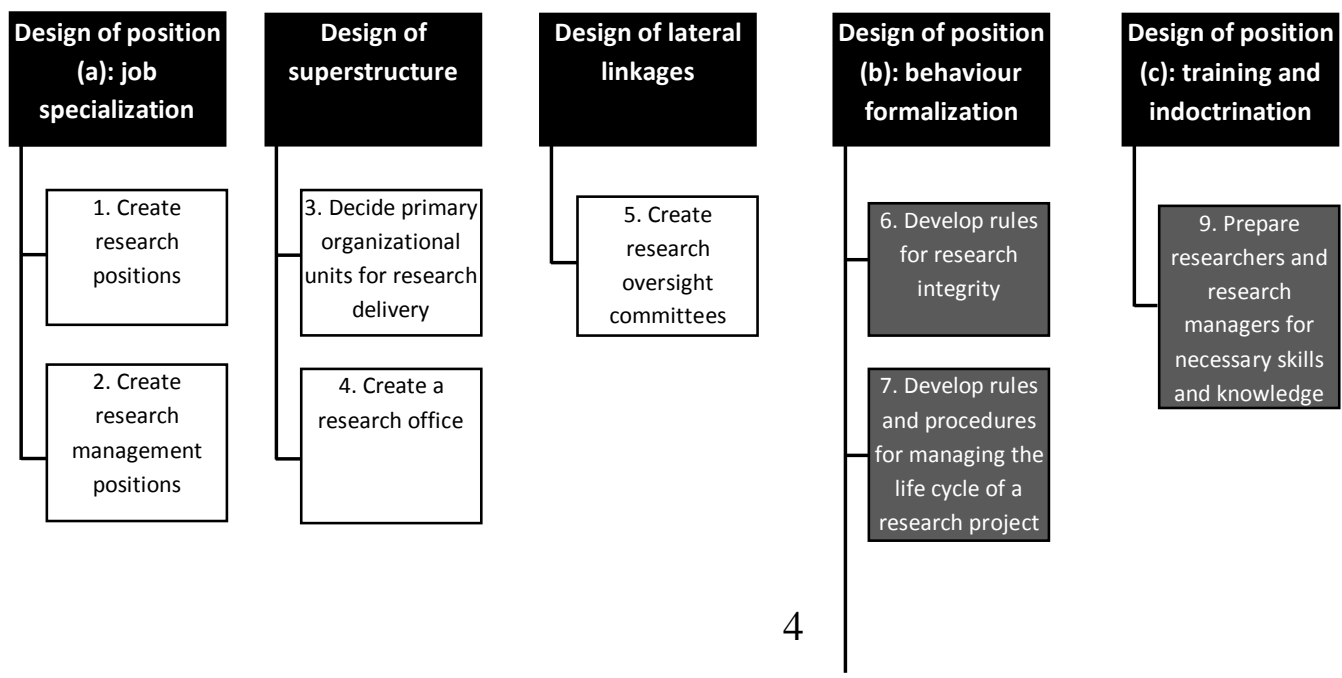


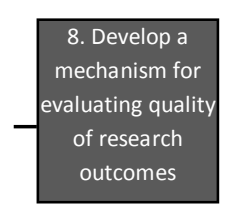

Fig 2 Generic parameters for organizing and structuring university research (adapted from Nguyen and Meek 2015)

\section{Design of positions (a): job specialization}

\section{Create research positions}

The first task in structuring and organizing research is to create research positions. Depending on the intensiveness of research activities and probably how research is funded, academic positions may be specialized into research and teaching combined or research-only positions. Concerning level of expertise, universities may categorize research and teaching combined positions into lecturers, senior lecturers, associate professors, and professors. Research-only positions may be classified into research fellow, senior research fellow, principal research fellow, and professorial research fellow, or something similar ${ }^{2}$. It should be noted that due to how research is funded, most of these research fulltime positions have been created recently and the majority of these positions may be employed on fixed term contracts (Broadbent, Troup, and Strachan 2013).

\section{Create research management positions}

In structuring and organizing research, universities need to create appropriate research management positions. For the eight universities both within and beyond OECD countries in a study examined by (Connell 2004), this task was found to be a key to building research capacity and enhancing research performance. In Australia, for example, at the institutional level, a Deputy Vice-Chancellor Research often oversees all research activities of the university. To assist the Deputy Vice-Chancellor Research to execute various areas of research management, there may be a number of other senior positions such as Pro Vice Chancellor Research Partnerships; Pro Vice Chancellor Research Collaboration; Pro Vice Chancellor Research Strategy, etc. At the faculty level, an Associate Dean (Research) is normally responsible for the academic research management matters. In addition, to support the Dean in managing the administrative side of research, a Faculty Research Manager is often created.

\section{Design of superstructure:}

\section{Decide primary organizational units for research delivery}

In structuring research, universities have to decide where the primary organizational units are located for research delivery. The basic units or building blocks of a university are academic departments. These are traditionally the basic units for organizing both teaching and research activities. However, in some universities, related academic departments are now being grouped into "faculties", "colleges", or "schools" (Taylor 2006). Within schools, staff may be clustered by research group. Existing alongside or within the schools may be research centres or research institutes. Recently, due to an increasing emphasis on interdisciplinary research, universities are increasingly employing an inter-disciplinary based research organization such as research clusters either within a university's boundary (Harris 2010) or beyond a university's border (Birx et al. 2013).

\footnotetext{
${ }^{2}$ In the US, for example, these full-time research positions may be classified into Research Assistant Professor (Associate Research Scientist or Assistant Researcher); Research Associate Professor (Research Associate or Research Scientist); Research Professor (Senior Research Associate or Senior Research Scientist)
} 


\section{Create a research office}

A research support office is a key structural and organizational ingredient to help create a helpful working environment for conducting research (OECD 2005). It serves as a centre for both internal research coordination and external linkages and its main role is to provide support to researchers throughout the university. The most common activities performed by research offices are: coordinating the overall university strategy in research, providing information and advice about funding opportunities, assisting and directing costing and pricing procedures, coordinating major research initiatives, giving advice on legal and ethical aspects of research and intellectual property, and developing a code of practice for the conduct of good research (Taylor 2006)

Notably, much of the work done by research offices is advisory in nature. Research officers should not merely be regulators and enforcers of the rulebook. Instead, they should be de facto members of the research team who can give helpful and constructive advice (Taylor 2006). University research support should be professionalized so that academic staff can be released from the administrative burden and focus on research. The challenge is to "establish productive relations with the faculty and departmental levels so as to enable creativity at the local level, while achieving institution-wide research goals and to work in ways which achieve a productive balance between the collegial and the managerial" (Connell 2004).

\section{Design of lateral linkages:}

\section{Create research oversight committees}

Apart from designing individual positions and vertical organizational units, universities also need to achieve mutual adjustment for coordination via linkages that are lateral. Research oversight committees are one formal device for universities to link the organization laterally. In other words, apart from appointing individuals to executive and management positions, universities also need to establish committees that facilitate policy and administrative development and monitoring of activities across different management portfolios. These committees may be standing or ad hoc. The numbers and functions depend on each organizational context. These committees are expected to add value to the operations of the institution. There may be cross-portfolio committees and specialist committees. In order to make them work effectively, universities should induct and train committee members so that they will be able to add full value to the work and challenges that they are asked to address (Pettigrew et al. 2013).

\section{The Five Less Visible Elements}

The five less visible parameters are: (6) develop rules for research integrity; (7) develop rules and procedures for managing the lifecycle of a research project; (8) develop a mechanism for evaluating the quality of research outcomes; (9) prepare researchers and research managers for the necessary skills and knowledge; and (10) decide vertical and horizontal decentralization. These parameters are regarded as less visible because, after these tasks are carried out, no specific positions occupied by human actors are created. The end products are often a number of policies or knowledge and skills.

\section{Design of positions (b): behaviour formalization}

\section{Develop rules for research integrity}

To maintain scientific excellence and keep the public's trust, universities need to develop rules for research integrity (Committee on Assessing Integrity in Research Environments National Research Council \& Institute of Medicine 2002). For a researcher, integrity refers to the individual's commitment to intellectual honesty and personal responsibility. For a university, it is a commitment to building an environment that promotes responsible conduct which can be achieved through embracing standards of excellence, trustworthiness, and lawfulness, not only in policy documents but also in the shared perceptions of university researchers and administrators. 
Ideally, the task of promoting research integrity should be carried out jointly by various stakeholders: professional bodies, governments, research institutions, and individual researchers. While professional societies may have codes of ethics and, in a few cases, a comprehensive description of responsible research practices (see e.g., National Academy of Sciences 1995), governments may pass laws on the responsible conduct of research. At the organizational level, universities are often required by law to develop policies to ensure institutional compliance with laws, regulations, guidelines, and codes of practice governing the conduct of research. Thus, apart from promoting the generally shared values for the responsible conduct of research such as honesty, accuracy, efficiency, and objectivity (Steneck 2007), universities need to develop policies to ensure research integrity at various research stages. For example, in planning research, universities should ensure that the benefits that all humans gain from human research do not impose unacceptable burdens on some human research participants. In conducting research, universities should have clear regulations for data management, supervisor and trainee responsibilities, and research collaboration. In reporting and reviewing research, adequate attention should be paid to authorship and publication matters.

\section{Developing rules and procedures for managing the lifecycle of a research project}

In order to standardize the work processes of research administration, universities need to develop appropriate policies and procedures for managing different research awards/projects throughout the various stages of a project lifecycle. The three main stages may include 'pre-award', 'in-award' and 'post-award'. Pre-award processes may cover procedures, guidelines and instructions for preparing and routing proposals for institutional review and submission to the sponsor. In-award processes may cover guidance for managing in line with the award terms and conditions. Post-ward processes may detail reporting obligations to the sponsor, financial reconciliations, forms and reports for the institution, and account closeout tasks.

\section{Develop a mechanism for evaluating the quality of research outcomes}

Universities also need to develop a mechanism for evaluating the quality of research outcomes. The main purpose of evaluating research outcomes is to have in place a basis for evaluating staff performance for promotion and other purposes. This task is critically needed in jurisdictions that have established national research quality reviews such as the UK and Australia. ${ }^{3}$ Three main mechanisms used by universities for measuring the quality of their staff's research outcomes are: publication counts, peer review, and bibliometrics.

While publication counts involve simply counting the total number of publications and patents a researcher or a department produces, peer review is the use of fellow academics to "certify the correctness of procedures, establish the plausibility of results, and allocate scarce resources" (Chubin and Hackett 1990). The purpose of peer review is to assess whether a certain grant application is approved prior to the commencement of a research project or whether a manuscript resulting from a research project is accepted to be published in a scholarly journal (Abate 2004). Bibliometrics is the combination of several quantitative indicators (such as publication numbers, citation rates) and journal impact factors. A citation rate is the number of times a particular reference has been cited during the previous year as initially indexed by the Institute for Scientific Information (ISI) in its Science Citation Index (SCI). Journal impact factors are mean citation rates for journals, which are published separately by ISI as the annual SCI Journal Citation Reports.

\footnotetext{
${ }^{3}$ Recently, some governments have developed national, research-quality frameworks that serve a number of purposes but, most importantly, they provide consistent and comprehensive approaches to assessing the quality and impact of research activities in universities, particularly publicly funded research, e.g., the British Research Assessment Exercise (RAE) and its successor the Research Excellence Framework (REF), the Australian Excellence in Research for Australia (ERA), the New Zealand Performance-Based Research Fund (PBRF), and the South African National Research Foundation's researcher rating system.
} 
Among the three methods, bibliometrics seems to be the most advanced method for assessing research quality (Adams 2009). Bibliometrics combines both the peer review and publication count methods. Additionally, by using citation rates and impact factors, this method enables comparative analysis at the individual, departmental, as well as institutional levels. As a result, this method has been widely supported (Moed et al. 1985; Taylor 2011). However, the bibliometrics method also has some limitations such as the unreliability of the databases used for calculating citation rates and journal impact factors (Adams 2009; Paul 2008).

\section{Design of positions (c): training and indoctrination}

\section{Prepare researchers and research managers for necessary skills and knowledge}

In designing research and research management positions, universities also need to prepare researchers and research managers for necessary skills and knowledge. Although most researchintensive universities hire only adequately trained professionals $(\mathrm{PhD}$ graduates) to work as lecturers or research fellows, in a number of newly upgraded universities, many of the lecturers may not yet have undertaken research training courses. Therefore, research training should be considered as a continuing on-the-job process for academics.

Universities should also provide adequate training for research managers. As most of the research management positions have been created relatively recently (Nguyen and Meek 2015), universities cannot expect research leaders and managers to have acquired all the necessary skills and knowledge prior to taking up their positions. Instead, universities should, on the one hand, describe the expected behaviour and qualities of the different research management positions. On the other hand, they should provide professional development to up-skill the capabilities of these research leaders and managers so that they can meet the new work demands.

Design of a decision-making system:

\section{Decide vertical and horizontal decentralization}

A decentralized structure, both vertically and horizontally, appears to be most suitable for research to take place. This is because universities are professional organizations (Mintzberg 1979). In these organizations, standardization of skills, not work processes, is what largely coordinates organizational members' work. Decision power is concentrated largely in the operating core, that is, the academics. The organization is strongly decentralized in the vertical dimension because this power rests at the very bottom of the hierarchy. And it is strongly decentralized in the horizontal dimension since this power rests with a large number of non-managers, namely the operators. A decentralized structure, both vertically and horizontally is strongly required for research to thrive.

In summary, above are the ten generic elements of structuring and organizing research. Using these 'ideal' elements of research organizational structure as a conceptual framework, this study examines the extent to which these elements are displayed at four leading Vietnamese universities and suggests some strategies for improvement. More specifically, this study asks the following questions: (1) What is the current organizational structure of the four case-study Vietnamese universities, particularly in terms of research management? (2) What are these university leaders', managers', and academics' perceptions of the effectiveness of their current structures? And (3) How can the structures be improved to best support research?

\section{Methods}

This study is primarily qualitative - "understanding of the social world through an examination of the interpretation of that world by its participants" (Bryman 2004: 266). This approach is well aligned with the objectives of this study, which aims to provide a rich description of the effectiveness of research organizational structure at leading Vietnamese universities (the social world) through the perceptions of university academics and managers (participants). 
The study conducted 55 semi-structured interviews. The purpose of the interview was to gain respondents' perceptions on the availability, appropriateness and effectiveness of current research organization and structure. The participants consisted of individuals directly involved in research and managing research at the case-study universities, including: 6 senior university leaders; 9 administrative managers; 18 deans/deputy deans; 6 directors of research institutes; and 16 lecturers. Each interview lasted from 45 to 60 minutes. The participants were identified based on the suggestions of the "gatekeepers" or the primary point of contact at each university. As a local expert, these "gatekeepers" had the best knowledge of who the research active lecturers and/or deans/deputy deans were in their university.

The interviews were conducted in Vietnamese and transcribed into Vietnamese before analysis; then supporting quotes were translated to English. The computer-assisted qualitative data analysis software NVIVO 9 was used to analyze the data. As stated, Nguyen and Meek's (2015) framework on structuring and organizing university research is used as a tool to analyze the empirical data. The study used a cross-case synthesis technique (Yin 2009). This means that answers from each individual participant and university were not reported separately but were aggregated. A pattern-matching logic was used by comparing the empirical findings with those offered in the literature. Similarities were kept before any new categories were added.

In selecting sites for the study, we considered four criteria: (1) university type (national, regional, normal); (2) specialization (i.e. engineering, natural sciences, medical sciences, and economics, etc.); (3) research capacity and performance (staff with $\mathrm{PhD}$ qualifications, teacher/student ratios, research publications, and research grants history) and (4) location (Southern, Central and Northern). Due to the limited research capacity of regional, Southern and Central universities, the final sample of four universities covered most of these criteria, excluding location criterion, and the inclusion of a regional university. More specifically, each of these four universities specializes in a collection of related disciplines, namely engineering, natural sciences, health care and economics. One is a university member of one of the two Vietnamese national universities that report to the prime minister; two universities are managed by the Ministry of Education and Training and one is administrated by a line ministry. They are all identified as key universities, which are expected to become leading universities in Vietnam, especially in research. Although it has not been articulated in policy documents, these four universities are expected to serve as models for other institutions charged with developing a broad array of higher education teaching and research functions; they are not intended to be models for centres of research excellence. Table 1 presents the four universities' selected demographic data.

Table 1: The four universities' selected demographic data (Nguyen 2013)

\begin{tabular}{|c|c|c|c|c|c|c|c|c|c|c|c|c|}
\hline University & Students & Academics & \begin{tabular}{|c|} 
Student/ \\
Teacher \\
Ratio
\end{tabular} & $\begin{array}{c}\text { Professors/A } \\
\text {.Professors }\end{array}$ & $\begin{array}{l}\text { Academics } \\
\text { with a PhD }\end{array}$ & \begin{tabular}{|c|} 
Academics \\
with a \\
Masters
\end{tabular} & \begin{tabular}{|l|} 
National \\
research \\
projects
\end{tabular} & \begin{tabular}{|l|} 
Ministry \\
research \\
projects
\end{tabular} & \begin{tabular}{|c|} 
Institutional \\
research \\
projects
\end{tabular} & \begin{tabular}{|c|} 
Domestic \\
research \\
publications \\
\end{tabular} & $\begin{array}{c}\text { International } \\
\text { research } \\
\text { publications }\end{array}$ & $\begin{array}{c}\text { Academic } \\
\text { year }\end{array}$ \\
\hline $\begin{array}{l}\text { The natural } \\
\text { sciences }\end{array}$ & 4,800 & 358 & 13,4 & $31 \%$ & $69 \%$ & $26 \%$ & 28 & 167 & 125 & 321 & 205 & 2011-2012 \\
\hline The engineering & 42,000 & 1,266 & 33 & $14 \%$ & $47 \%$ & $45 \%$ & 48 & 189 & 246 & 300 & 100 & 2010-2011 \\
\hline The economics & 45,000 & 759 & 59 & $15 \%$ & $34 \%$ & $52 \%$ & 5 & 15 & 50 & $\mathrm{n} / \mathrm{a}$ & 30 & 2011-2012 \\
\hline $\begin{array}{l}\text { The medical } \\
\text { sciences }\end{array}$ & 5,000 & 255 & 20 & $60 \%$ & $80 \%$ & $20 \%$ & $\mathrm{n} / \mathrm{a}$ & $\mathrm{n} / \mathrm{a}$ & $\mathrm{n} / \mathrm{a}$ & $\mathrm{n} / \mathrm{a}$ & $\mathrm{n} / \mathrm{a}$ & 2011-2012 \\
\hline
\end{tabular}

\section{Findings}

Table 2 provides a check list of the extent to which the above ten key elements for organizing and structuring university research have been implemented at the four Vietnamese case-study institutions (an item rated 1 = "inapplicable"; 2 = "to some extent applicable"; 3 = "applicable"). It appears that, 
on the one hand, the Vietnamese universities have accomplished a number of the more visible tasks in organizing and structuring research. On the other hand, the other less visible tasks of organizing and structuring research remain neglected.

Table 2: Structuring and organizing research at the four Vietnamese universities (adapted from Nguyen and Meek 2015)

\begin{tabular}{|c|c|c|}
\hline \multirow{5}{*}{$\begin{array}{c}\text { More } \\
\text { visible } \\
\text { tasks }\end{array}$} & 1. Create research positions & 2 \\
\hline & 2. Create research management positions & 2 \\
\hline & 3. Decide primary organizational units for research delivery & 2 \\
\hline & 4. Create a research office & 2 \\
\hline & 5. Create research oversight committees & 3 \\
\hline \multirow{5}{*}{$\begin{array}{c}\text { Less } \\
\text { visible } \\
\text { tasks }\end{array}$} & 6. Develop rules for research integrity & 1 \\
\hline & $\begin{array}{l}\text { 7. Develop rules and procedures for managing the lifecycle of } \\
\text { a research project }\end{array}$ & 2 \\
\hline & $\begin{array}{l}\text { 8. Develop a mechanism for evaluating the quality of research } \\
\text { outcomes }\end{array}$ & 1 \\
\hline & $\begin{array}{l}\text { 9. Prepare researchers and research managers for necessary } \\
\text { skills and knowledge }\end{array}$ & 1 \\
\hline & 10. Decide vertical and horizontal decentralization & 1 \\
\hline
\end{tabular}

\section{The Vertical Line of Research Management and their Functions}

It seems that the four universities have clearly specified the vertical line of research management authorities (see Figure 2). At the institutional level, the Rector and Vice-Rector (research) are in charge of overseeing the overall university's research performance. They are supported by a Research Office which is led by a Director who is assisted by one or more Deputy Directors. At the faculty level, the Dean takes the ultimate responsibility for his/her faculty's research activities. Except for the economics university, all of the other three universities create the position of a Deputy Dean (Research) who assists the Dean in looking after the faculty's research performance. 


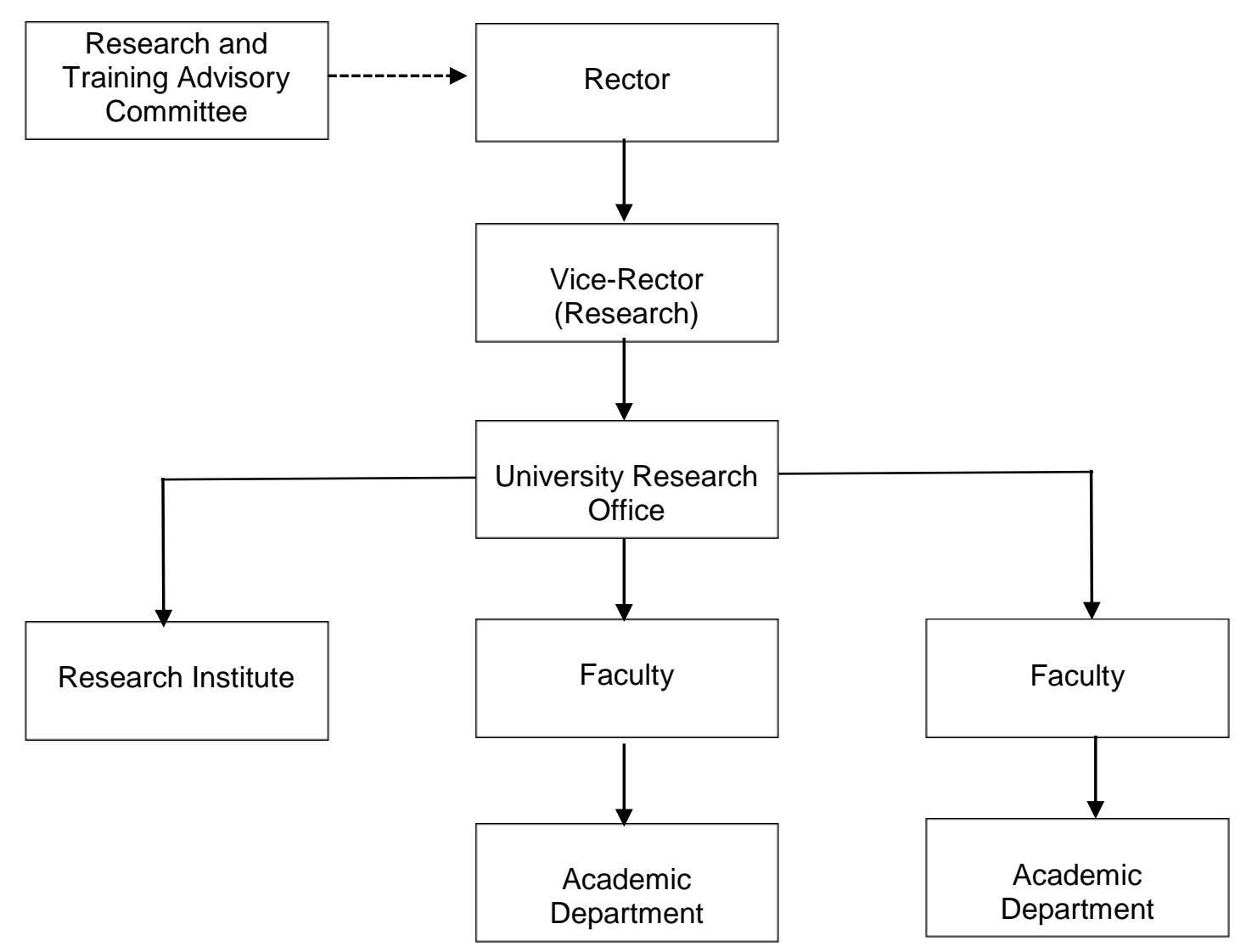

Fig 3 The research organizational structure chart (Source: Authors)

A research office is created at all of the four universities. The roles of a research office are described generally in the University Regulations (Thủ tướng Chính phủ 2010) and more specifically in 'Regulations for Operating Science and Technology Activities' (Quy chế hoạt động khoa học và công nghệ) ${ }^{4}$ at two of the four universities. This office is expected to exercise all of the four functions of management classified by Schermerhorn et al. (2011): planning, organizing, leading, and controlling. Firstly, the planning tasks cover: developing both strategic and operational plans for research development and technology transfer; facilitating the application of research results into practice; actively facilitating partnerships with both international and local research institutions and industries. Secondly, the organizing function includes: developing regulations on university research management; advising the rector on allocating institutional research projects; and organizing institutional-level research seminars and conferences. Thirdly, the leading role is demonstrated through guiding researchers to follow appropriate administrative procedures and supporting them to complete their projects on time. Finally, the controlling tasks consist of keeping a record of all research projects undertaken by university staff; monitoring the progress of their projects; establishing committees and organizing meetings to assess research project outcomes; and holding an annual meeting to evaluate the university's yearly research performance and to celebrate researchers' achievements in research.

Faculties or Research Institutes are the primary organizational units for research activities. Research Institutes are stand-alone units that report directly to the rector. In terms of their administrative level, they are ranked equally with Faculties. The amount of research implemented by a Research Institute is

\footnotetext{
${ }^{4}$ Each university was expected to specify the University Regulations' general national-level regulation at an institutional level. However, regarding the research office's role, only two of the four universities issued the so-called 'Quy chế hoạt động khoa học và công nghệ' (Regulations for Operating Science and Technology Activities)
} 
often larger than that carried out by a Faculty. Each university has some Research Institutes. They can be regarded as "centres of research excellence". At three of the four universities, there is a tendency to change the name of some or even most of the existing "faculties" to "institutes". The indication is that, to some extent, these newly named "institutes" have focused on research better than those named "faculties". More importantly, in the long run, the university expects these newly named institutes to focus more on research.

Faculties and Research Institutes have four main research management responsibilities (Thủ tướng Chính phủ 2010). Firstly, they organize research and technology development activities. Secondly, they actively participate in international cooperation projects and in cooperating with other R\&D organizations and production, and service enterprises in order to link training with research, industries, and social activities. Thirdly, they manage the quality of research and technology development activities. Finally, they assess the performance of the department's managers, lecturers, and researchers.

The majority of research activities are conducted by tenure and full-time fix-termed contract academics. These academic positions are categorized into probation lecturers, lecturers, lead lecturers, and senior lecturers. Research only positions (research assistants, researchers, lead researchers and senior researchers) only existed at research institutes outside universities (Quốc hội 2010). They had not yet been created at the four universities. All of the four universities created a Research and Training Advisory Committee. The ultimate responsibility of this committee is to advise the rector on matters regarding both research and training.

\section{The Vertical Line of Management's Effectiveness}

Rectors and Vice-Rectors Research: More Effective as a 'Disturbance Handler' than as an 'Entrepreneur'

Most of the respondents agreed that, compared to what is stated in the policy documents (Quốc hội 2012), in practice the roles of the rector and vice-rector (research) are adhered to quite firmly. The rector is ultimately responsible for research management. Being considered as an assistant to the rector in executing university research, the vice-rector (research) is in charge of the day-to-day administrative management of research. This role is relevant because "the rector has so many tasks to do, he can't work as a rector as well as overseeing the university's research activities. So it is quite sensible to have a vice-rector (research)" (Lecturer, Economics).

The majority of the participants did not complain directly about the university's top research management positions such as the rector and vice-rector (research). This is probably due to the Vietnamese culture of not making negative comments about leaders in public. However, the respondents did indicate that they were not completely pleased with how each position/role was performing. They expected that each authority in a research management position should have been more committed to doing his/her job.

Although almost all respondents did not complain about how top university leaders manage research, a few criticized their "invisible" roles:

My university has all of these positions (rector, vice-rector (research)). However, to be honest with you, I don't see how effectively they are performing. Only when problems arise, the rector and vice-rector would get involved to solve them. If not, all other work is done slowly by their subordinates. Of course, there are one or two meetings per year to evaluate the university's research performance. However, their main role is to present a report of research activities. Apart from that, their role is very blurred (Dean, Applied Medical).

This comment is in the minority; however, it is very critical. It appears that in their management role, top authorities are perceived more as a 'disturbance handler' - dealing with unforseen events than as an entrepreneur - taking voluntary actions to bring about controlled organizational change (Mintzberg 
1973). As top university leaders, Rectors and Vice Rectors should take more of the entrepreneurial role than that of a problem solver.

The Research Office: More Effective in "Organizing" and "Controlling" than on "Planning" and "Leading" Roles

Most of the respondents appreciated the effective role of the research office in disseminating a funding agency's calls for research proposals and in forwarding the researchers' research proposals to funding agencies. For research projects carried out in the university name, the research office also seems to monitor their progresses very well by 'looking at the progress of a project in terms of timelines or organizing assessment committees' (Vice-Rector, Research). Apart from these inward informational and monitoring roles, participants hardly appreciated any other roles performed by the research office. The participants seem to be most displeased with the research office's planning role, spanning role and its oversight of projects funded by non-government sources:

My perception is that the research office only does their administrative work generally. Their involvement in developing the vision and strategic plans for the university research is very weak (Manager, Human Resources).

The research office should communicate widely to bring more projects to the university. They should cooperate better with the administration office and the international relations department ... Their main task is to manage the paperwork of ongoing research projects (Manager, Postgraduate Department).

The research office hasn't been able to manage projects funded by non-government agencies. They don't know their research topics or research processes; they only manage some paperwork related issues such as finance or administrative procedures. Everything else is done by the researchers and their partners (Deputy Dean, Basic Medical).

It appears that the research office is not yet able to perform all of its functions effectively. The research office seems to have carried out the "organizing" and "controlling" roles more effectively than the "planning" and "leading" roles (Schermerhorn et al. 2011).

\section{Faculties Appear to be Much More Passive and Less Effective than Research Institutes}

In practice, Research Institutes seem to have performed their research roles very well because their central mission is to do research. Particularly, at the engineering university, these institutes are often led by internationally qualified academics. One institute attracts a critical mass of highly qualified overseas trained Vietnamese academics to the institute. Another maintains an effective research cooperation program with an overseas research institution. It attracts regular international research fellows coming on one to two year fellowships. These research institutes appear to operate similarly to other research institutes in the more developed universities. These internationalized aspects make them distinctive from other faculties and research institutes.

Faculties' roles in managing and promoting research, however, appear to be very vague. The four universities do not appear to have defined Deans' responsibilities and accountabilities clearly with respect to research management. On the one hand, Faculties are not allocated any budgets under their control. On the other hand, Deans are under almost no pressure to attract funding for research or any other fundraising activities. Although the University Regulations state that Deans are responsible for managing the quality of research and technology development, most Faculties do not keep a detailed record of their research performance:

Faculties only keep records of teaching programs and textbooks; they don't keep a record of research. I can guarantee that $80 \%$ of faculties are like that (Manager, Research Office). 
Faculties and Research Institutes are charged with managing the performance of lecturers and researchers; however, only one Director of a Research Institute (in Applied Sciences) mentioned how his institute set a clear and specific criterion for research performance. Other Deans or Directors of Research Institutes did not comment on this at all. Most Faculties did not develop a research plan either.

Deans may care about how to get two research projects this year for their faculties, but if being asked what research their faculty has been doing in the past four years or what their research plans are for the next two years they don't know (Manager, Research Office).

Overall, whether research at a particular faculty develops or not may depend entirely on the Dean's preferences. In fact, "Departments with Deans that are more committed to research have more research projects. Departments with Deans more interested in teaching have fewer" (Manager, Research Office).

Indeed, most of the participants perceived the main responsibility of a Faculty only as liaising between the university research office and faculty members and vice versa. Once a call for research proposals is announced, Faculties receive the announcement from the research office and pass it on to faculty members. After collecting and selecting academics' research proposals, Faculties then send the proposals to the Research Office for the Rector's approval. Once approval has been granted, Faculties are responsible for managing the progress of the institutionally funded research projects only. Oversight of ministry or nationally funded projects remains the Research Office's and researchers' responsibility.

One dean complained that:

The lecturer signs the research contract with the Vice-Rector (research), not with the Dean. However, if things don't go as planned, or when the Research Office may urgently need to know the progress of these research projects, they ask the Deans for help (Dean, Engineering).

This Dean continued to comment that "this is an unreasonable work procedure that needs to be reconsidered". This seems a reasonable claim because, while Deans are not charged with monitoring the progress of such projects, these projects are carried out by staff whose performance eventually affects the overall performance of a Faculty. It appears inappropriate not to get the Dean involved in monitoring these projects from the beginning. Ironically, when something goes wrong with these nonuniversity-funded research projects, the Deans do eventually get involved.

$\underline{\text { Research-focused Academic Positions: Non-Existent }}$

At the time the data for this study was collected, research-focused academic positions did not exist at the four universities. Directors of some active Research Institutes considered this as a gap in the academic management system that needs to be filled. It should be noted that such positions are still centrally created and designed by the Ministry of Internal Affairs, and probably because in the past universities were not expected to do research, research-only positions were not created in such organizations. However, this was not a major problem in structuring and organizing research.

\section{The Research and Training Committee: A Highly Appropriate but a Mixed Perception of Role}

In general, the existence of the research committee was thought to be highly appropriate. The most evident role of this committee is to advise the rector on making a strategic plan. For example, at the engineering university, "if the university wants to set up a new department, the committee will consider whether such establishment is necessary or whether the conditions are ripe for doing so"(Manager, Human Resources). At the medical university, the standing research committee approved university-funded research proposals. 
As an advisory body, the research committee's degree of influence differs across the four universities. At the engineering university, it was observed that, "in a number of cases, the research committee wins over the Rector, and the Rector has to accept the committee's advice" (Director, Research Institute, Applied Sciences). However, at the natural sciences university, the rector cautioned that, "however important the Research and Training Committee might be, it only has an advisory role, not a decision-making role. The Rector can choose to take their advice or not. It's not necessary that s/he has to".

The role of the research committee was enhanced at the engineering university by the establishment of three interdisciplinary sub-committees to decide institutional research priorities and to help academics develop competitive research proposals. However, at the medical university, this role was not regarded with the same degree of importance:

I am also a member of the research committee, but not a standing member. There hasn't been any meeting held since last year. I am not quite sure about its role. Their role is quite insubstantial. Possibly, they only work when there is a problem? I don't see them work very regularly. Or only the standing committee meet, I am not sure (Dean, Applied Medical).

\section{The Lack of an Effective Research Behaviour Formalization System}

Nguyen and Meek (2015) identify 3 tasks in formalizing research behaviours: (1) develop rules for research integrity; (2) develop rules and procedures for managing the life cycle of a research project; and (3) develop a mechanism for evaluating quality of research outcomes. The four case-study universities did develop guidelines for academics to manage their research projects; however, codes of ethics for ensuring research integrity either did not exist or existed only for nominal sake. The mechanisms for evaluating the quality of research outcomes did not seem to exist, either.

Regarding research integrity, in a more developed research system such as in America or Australia, universities are requested by law to develop policies to ensure institutional compliance with laws and codes of practices governing the conduct of research (Committee on Assessing Integrity in Research Environments et al. 2002). Among the four case-study universities, the medical university is the only one that adopts a regulation for research ethics. The codes of ethics are required by the medical professional society, not the university's proactive strategy for promoting research integrity. In reality, the participants seemed to mention its existence more than its role in managing the researchers' ethical behaviour.

Concerning research quality assurance, the literature suggests using peer review and bibliometrics methods as mechanisms for evaluating research quality (Benos et al. 2007; Bornmann and Daniel 2005). However, the four Vietnamese universities apply almost none of these practices. One participant commented that university leaders often talked about how to improve research quality in general, however, in practice, no specific indicators or standards were given. For another participant from the medical university, "the only mechanism that I can see is our ethics committee. If a research project involves human subjects, then they need to have ethics clearance"(Dean, Applied Medical). Some participants explained that the universities did not develop any concrete quality assurance systems for institional-level research projects because the funding was too small. The interest appears to be more on successful completion per se of a project, than the quality of the product:

The research office only checks against the list of what you proposed to do to see whether you have done them all. If you do, you pass, if you do more, you can get a "good" ranking (Lecturer, Basic Sciences).

Indeed, although the university had a criterion for classifying a research project into "excellent", "good", and "pass" rankings, lecturers said that they just did what they had proposed to do without thinking much about what rank the project would get. 
In Vietnam, in general, and at the four case-study universities, in particular, to assess a research proposal or evaluate a research project's outcomes, an ad hoc evaluation committee is often used. This committee makes judgments based on the assessment criteria developed by a corresponding funding agency. Their judgments are often considered as the ultimate evaluation of research. A number of participants severely criticized this evaluation method. They complained about the unclear procedures and criteria for assessing research proposals at all administrative levels:

When a research proposal is submitted to the institute, the institute will assess it. However, the method for assessing it is not clear. It's unknown to researchers based on which criteria a certain proposal is selected over another one (Lecturer, Engineering).

There are still a lot of problems in our system of assessing a research proposal. Somehow we must change it to avoid bias because in a certain assessment committee, there may be a practice that if I like $\mathrm{Mr}$ A or Mr B, I will support his research proposal, if I don't, I will not (Lecturer, Applied Sciences).

In further examining the regulations for approving a research project from different funding agencies, it was revealed that there was a set of clear criteria and scores allocated for different areas of assessment such as the quality of proposals and the capacity of potential researchers. However, these funding organizations did not use independent anonymous referees to assess the proposals. Instead, they created an evaluation committee of 9-11 members. These people met and assessed all research proposals of the same discipline. Prior to their meeting, only two committee members would have read and assessed the proposals. If the committee lacked the relevant expertise, two external experts might be invited to complete this task. Other committee members would assess the proposals based on these two pre-evaluation reports. Therefore, even though participants complained about the unclear criteria for assessing a research proposal, they might actually mean the perceived subjective decisions made by the committee members. Because the evaluation committee directly decides a research proposal's final outcome, the existing evaluation procedures appear to be based on a "judge, jury, and hangman" practice.

After finishing a research project, instead of having to show their research outcomes through different forms of publications, the researchers were required to defend their research results in front of an evaluation committee. Some participants pointed out a few problems associated with this practice. These include the summative nature of evaluation; the unprofessional assessment practices of the evaluators; and some negative influences of the face-to-face evaluation method.

Firstly, the assessment was summative rather than formative:

A lot of research projects are complimented by the committee clapping their hands after an evaluation. The committee then may go out for a celebratory lunch, and each member may receive an envelope with VND 100,000 (equivalent to USD 5) inside for their evaluation time. However, a research project literally ends there. The research report will go into a cabinet forever. This is a reality that we should uncover (Lecturer, Natural Sciences).

Secondly, the assessment criteria appear to be poorly adhered to in practice:

Although we have a committee to evaluate a research project, and each project is given a score for its quality, the common scene is that all projects are evaluated as satisfactory without necessarily attaining high quality (Lecturer, Economics).

One participant commented that, although both marks and comments were expected, qualitative comments were often inadequately given. In a section that requires the assessor to comment on whether a research project had achieved its objectives, the only comment written may be "enough and clear" (Manager, Humance Resources). This practice was considered "very subjective" (Director, Research Institute, Economics). 
Finally, it seems to be unfair to employ face-to-face evaluation. This practice may cause an unbalanced power position between the researchers and the evaluators. Instead of having a constructive, two-way, feedback conversation, this may create a "having the fox look after the chicken" situation. Some participants noted that, in some cases, despite knowing that the assessors might be wrong in their evaluation, a researcher might not dare argue against them. They were afraid that doing so might result in having their project assessed as having failed by these same assessors. In other words, by giving an assessment committee the right to judge the final result of a research project based mainly on their personal judgment, it is very difficult to limit bias. Probably, to help reduce bias, a research report should be reviewed independently before any committee can eventually make a final judgment.

\section{The Lack of a Vertical and Horizontal Research Decentralization}

The literature suggests that a decentralized structure, both vertically and horizontally is the most suitable for research to take place (Kirkland 2008; Edgar and Geare 2013). However, at the four universities, almost all participants complained about the bureaucratic administrative procedures for managing research. Some participants named this a "disease" in the whole administrative system of the country.

Now the bureaucratic disease in ministries and provinces are very serious, even at this university. Thus, lecturers may be able to get research funding but all paperwork procedures make them very tired. They have to "run" from the research office to the finance department (Dean, Engineering).

In carrying out research, researchers had to strictly follow all the steps that they had written in their research proposals. If they wanted to modify any details, they would need to apply for approval.

I can only buy an item for doing research if that item has already been approved in my original research proposal. If I want to change a certain item, I will need to apply for approval explaining why I need to change. It may take some months for me to get this kind of approval. Even for buying chemicals, for example, if I follow my original plan, I will need to submit some "fake" invoices just to show that I have chosen the cheapest offer. In practice, if I fail to use a certain chemical, I'll need to try another one. However, this means I don't follow my original proposal, and this is not allowed. Therefore, our current management practices are so problematic, they are not promoting people's talent and ability yet. However, since we are working in this system, we have to obey its rules, otherwise we will be dismissed. But, clearly, these practices are preventing us from development (Manager, Research Office).

In finishing up a research project, procedures for clearing finance were also very cumbersome.

If research grant approving procedures demotivate lecturers, how a research project is assessed makes them frustrated ... For example, in a research project design, there may be a seminar. Each seminar attendee is given, in the past VND 50,000, then VND 70,000, and now VND 100,000 (equivalent to about USD 2.5, USD 3.5, and USD 5, respectively). To get financial clearance, a researcher may have to ask people who may or may not actually attend the seminar for their signature. These kinds of "charity" signatures exist everywhere in Vietnam, from Saigon to Hue (Lecturer, Natural Sciences).

In short, the lack of a decentralized structure seems to have prevented research to boost.

The Passive Roles in Improving Researchers' and Research Managers' Skills and Knowledge as a Continuous Process

Universities should prepare researchers and research managers for the necessary leadership and management skills and knowledge. This task involves upgrading the knowledge and skills of both 
researchers and research leaders and managers so that they are capable of successfully doing and managing research. In doing so, universities may need separate professional development programs and on-the-job training processes. Yet, at the four universities, the task of up-skilling academics' research skills does not appear to have been systematically pursued by any university agenda. Universities do not seem to have put any money aside to support lecturers in attending international conferences or professional development courses. It appears that lecturers are mainly in charge of upskilling their research skills themselves. The job of professionally training research leaders and managers also appears to be neglected. This topic was hardly raised by any participants.

\section{Discussion}

It appears that despite having the appearance of a functioning organizational structure for leading and managing research, the management of research has not yet been professionalized at the four case study universities. Rectors and Vice-Rectors Research were perceived more as a 'disturbance handler' (who deals with routines and unpredictable events) than as an 'entrepreneur' (who takes initiatives in bringing about revolutionary changes in research leadership). In contrast, in today's global research context, as increasingly, effective research requires collaborative networks of researchers between universities and firms and across national borders, an entrepreneurial strategy in research leadership is more important than traditional managerial skills (Hansson 2008).

The role of the research office seems to be vague. Being generally perceived more as an 'organizer' and a 'controller' than as a 'planner' and a 'leader', the research office did not seem to have fully utilized their capacity. The research office was supposed to coordinate the development of a university-wide research policy document. However, such formal research policy document existed at only two of the four universities. Even at these organizations, the respondents perceived a considerable gap between the research office's expected and actual roles. In theory, the research office was responsible for developing both strategic and operational plans for research development; however, little of this occurred in practice. This situation seems to be contrary to the desirable professionalized, advisory and consulting nature of an effective research office (Taylor 2006; Connell 2004)

Faculties work as the primary unit for research delivery; however, faculties did not have a clear role definition with respect to managing research. Based on the National University Regulations, universities are expected to specify faculties' responsibilities for overseeing and facilitating research. However, in practice none of the four universities did so. Faculties received almost no direct funding for research development. Deans seemed to be under no pressure to attract research funding and/or to increase faculty's overall publication outputs. At one university, faculties were not directly involved in managing research projects funded by non-university funding organizations. Only when some problems occurred (e.g. non-completion of a research project), deans became involved. This situation differs from that of a research intensive university in which Deans and Heads of Departments in developed research systems often have direct responsibilities for research activities conducted by their faculty members (Pettigrew et al. 2013).

These findings are well-aligned with the low level of management functions and role clarity in various research leadership and management roles depicted in some emerging studies on university governance and management in Vietnam. For example, in examining the roles of the Heads of Department at a newly upgraded Vietnamese university, Nguyen (2013b) found that the Heads of Department enjoy a low level of autonomy and act more as managers than as leaders. In assessing the degree of clarity in Hanoi University's tasks in promoting incentives for academic excellence, Ngo (2014) found that the University's policies for promoting academic excellence are vague. Most of the tasks expected to be fulfilled by university leaders' and department leaders' are 'routine'. Department leaders' specific actions to promote academic excellence appear infrequent.

To deal with these problems associated with the ineffectiveness of the 'design of positions' (Minzberg 1979), the four universities should professionalize and empower the vertical line of research management. They should define clearly the expected responsibilities and accountabilities of all 
research leaders and managers. They should also develop a transparent mechanism to ensure that these responsibilities and accountabilities are adhered to in practice. In searching for a new model of public university governance that promotes incentives for academic excellence for modern Vietnam, Ngo (2014) compares university governance models of Vietnam with those of Thailand, Hong Kong and China and finds that the higher the degree of organizational structure clarity, the more likely university leaders take actions toward achieving academic excellence (Ngo 2014). A clear role definition can provide the basis for university leaders and managers to take concrete actions for enhancing research development.

The four universities seem to lack an effective system for standardizing and formalizing research behaviours. In advanced research systems, such a formal research evaluation system often exists to regulate research behaviours and to ensure research quality before, during, and after a research project is undertaken. For example, after a research project ends, universities often use publication numbers and, later, citation rates as direct methods for assessing research quality and impact (Chubin and Hackett 1990; McNay 2010). At the four case-study universities, such a research evaluation system seems to be missing. It seems that researchers only needed to be accountable to a small group of people working as a research assessment committee established by corresponding research funding agencies. While in the past, these research evaluation practices seem to be prevalent in all former Soviet bloc countries, after the collapse of the Communist system, former communist countries have abandoned these ineffective practices to adopt the Western evaluation practices (Frankel and Cave 1997). However, in Vietnam such practices are still being applied to evaluate research. Research is a long-term process. Research results need feedback from the wider research community and often require a length of time before their impact becomes evident. Using a research assessment committee as an exclusive mechanism for evaluating the quality of research outcomes seems inappropriate.

The problems associated with bureaucratic administrative procedures reveal inadequacies in the decision-making system. While the literature strongly advocates decentralization both vertically and horizontally to facilitate research development (Edgar and Geare 2013; Taylor 2006), the current practices of funding a research project in Vietnam reflects quite clearly the legacy of a centralized planning management culture (Dao 2014). Instead of being judged on final outcomes of a research project in terms of publications, patents, etc., researchers seem to be "watched" too closely on how they use their research money (Ly 2013). By paying too much attention to compliance with detailed expenditure guidelines and financial accountability mechanisms, research funding organizations seem to indicate that they do not trust researchers. This rigid and over-regulated decision-making system may result in a blockage of creativity and researchers' low job satisfaction (Ly 2013). This will ultimately do more harm than good to universities and the society at large. This inadequate centralized decision-making mechanism should be improved so that researchers can concentrate on the main tasks of doing research instead of having to spend too much time on complying with detailed and rigid financial rules.

Vietnam is determined to integrate into the world's academic system, as reflected in the government's decision on 'Approving the project of international integration in science and technology to 2020' (Thủ tướng Chính phủ 2011). A prerequisite for successfully implementing this plan is to make sure that research practices in Vietnam align well with international practices and conventions. The four universities should create a more effective research evaluation system. For example, instead of using purely an evaluation committee to directly evaluate the quality of a research proposal or a research project's final outcome, peer-review should be properly employed. This may help to minimize assessor bias. Codes of research integrity should also be developed to make academics aware of and committed to research ethics and research excellence. Most importantly, a more decentralized system of research decision making should be created so that researchers can have a stronger say in deciding on how to manage their 'hard earned' research funds.

These suggestions are very critical for the four universities to improve research capacity and performance. However, these recommendations are easier said than done. The four universities may be active in redefining different research leadership positions; however, some other recommendations 
(such as the promotion of research integrity and research quality and decentralization of research governance) may go far beyond these universities' immediate control. By collaborating with different industrialized nations in establishing modern universities, Vietnam seems to be willing to learn from other developed countries' experiences. This paper argues that while best practices in research management could be learnt, they must be adapted to fit local contexts (Ngo 2014). In decentralizing the decision making system, care must be taken so that lower level management are capable of implementing the conferred autonomy (Tran 2014).

In formalizing research behaviours through improving the national research evaluation and research governance system, two aspects of bureaucratic reform need to be kept in mind: enabling and coercive bureaucracy (Adler and Borys 1996). Enabling bureaucracy is formalization that enables employees to better master their tasks or functions as a means. Coercive bureaucracy is a managerial attempt to coerce employees' effort and compliance. In formalizing research behaviours, the four universities should balance between these two types of bureaucracy. Also, the impact of formalization on employees' attitudes may be negative. For example, Woelert (2015) investigates the formalization dilemma in the governance of the public sciences and finds that while a strong reliance on formalized knowledge allows for 'a seemingly rational and efficient form of the control and coordination' of research activities', it also increases the risk that knowledge is used in governance contexts in 'superficial, unconsidered and ultimately unreasonable ways'. While research formalization is necessary, a relevant research governance system should be created so as to minimize dysfunctional behaviours on part of relevant individual and organizational actors in the public science system.

\section{Conclusions}

In conclusion, as university research management is an under-explored research topic, this article helps to enrich this body of literature by presenting empirical findings of how research is structured and organized at four leading Vietnamese universities. These findings suggest that, at the four Vietnamese universities, even though research has been formally structured and organized, the management of research has not yet been professionalized. Apart from completing a number of the more visible tasks, the four universities appear to have neglected most of the less visible tasks in structuring and organizing research. The academics' reaction to the four universities' research organizational structure indicates that it is insufficient to merely create a diagram of different research management positions and research delivery divisions. Underlying this visible diagram are a number of significant issues that universities need to address in order to boost research performance. These issues include: enhancing the research office and faculties' roles in managing research; developing rules for research integrity; evaluating the quality of research outcomes and decentralizing both the vertical and horizontal governance of research.

It is recommended that the four universities should pay adequate attention to these critical issues to develop a more complete structure for managing research, thereby creating a more effective system for formalizing research behaviours. It is also noted that due to the complexity of the problems identified, these suggestions are easier said than done. The application of these solutions may require not only organizational efforts but also the government, research funding agencies and the whole research community. The challenge here is not only to create and apply new research management practices but also to gain support from the whole research system. In other words, change is needed not just at a single organization, but at the system level as a whole.

\section{References}

Abate, T. 2004. What's the verdict on peer review. http://www.columbia.edu/cu/21stC/issue1.1/peer.htm. Accessed April 122013.

Adams, Jonathan. 2009. The use of bibliometrics to measure research quality in UK higher education institutions. Archivum Immunologiae et Therapiae Experimentalis 57(1): 19-32.

Adler, Paul S., and Bryan Borys. 1996. Two Types of Bureaucracy: Enabling and Coercive. Administrative Science Quarterly 41(1): 61-89. doi:10.2307/2393986. 
Altbach, Philip G., and Jamil Salmi. 2011. The Road to Academic Excellence The Making of WorldClass Research Universities. Washington: World Bank Publications.

Altbach, Philip G., and Jorge Balán. 2007. World class worldwide: transforming research universities in Asia and Latin America. Baltimore, MD: Johns Hopkins University Press.

Altbach, Philip Geoffrey. 2007. Peripheries and Centres: Research Universities in Developing Countries. Higher Education Management \& Policy 19(2): 111-134.

Bazeley, Pat. 2010. Conceptualising research performance. Studies in Higher Education 35(8):889903. doi:10.1080/03075070903348404.

Benos, Dale J., Edlira Bashari, Jose M. Chaves, Amit Gaggar, Niren Kapoor, Martin LaFrance, Robert Mans, David Mayhew, Sara McGowan, and Abigail Polter. 2007. The ups and downs of peer review. Advances in Physiology Education 31(2): 145-152.

Berg, Carin. 1995. Academy research institutes and universities. Higher Education in Europe 20(4): 157-160.

http://www.tandfonline.com/doi/abs/10.1080/0379772950200428?journalCode=chee20\&\#.V peZT0_QInk. Accessed 14/01/2016

Birx, Donald L., Elizabeth Anderson-Fletcher, and Elizabeth Whitney. 2013. Growing an emerging research university. Journal of Research Administration 44(1): 11-35

Bộ giáo dục và đào tạo. 2013. Số liệu thống kê GD\&ĐT năm 2013 (Statistics in Education and Training in 2013). http://moet.gov.vn/?page=11.11\&view=5251. Accessed 05/09/2013.

Bornmann, Lutz, and Hans-Dieter Daniel. 2005. Selection of research fellowship recipients by committee peer review. Reliability, fairness and predictive validity of Board of Trustees' decisions. Scientometrics 63(2): 297-320.

Bosch, Anita, and John Taylor. 2011. A proposed framework of institutional research development phases. Journal of higher education policy and management 33(5): 443-457. doi:10.1080/1360080x.2011.585742.

Broadbent, K., C. Troup, and G. Strachan. 2013. Research staff in Australian universities: is there a career path? Labour and industry: a journal of the social and economic relations of work 23(3): 276-295.

Bryman, Alan. 2004. Social research methods. New York: Oxford University Press.

Ca, Tran Ngoc, and Nguyen Vo Hung. 2010. Vietnam: Current Debates on the Transformation of Academic Institutions. In Universities in Transition: The Changing role and Challenges for Academic Institutions, eds. Bo Göransson and Claes Brundenius, 119-142. Singapore: Springer.

Chính phủ. 2004. Công văn số 1269/CP-KG, ngày 6/9/2004 về việc tiếp tục hoàn thiện mạng lưới các trường đại học, cao đẳng (Document number 1269/CP-KG, dated 6/9/2004 on continuing to develop a complete national network of universities and colleges).

Chubin, Daryl E., and Edward J. Hackett. 1990. Peerless science: Peer review and US science policy. New York: Suny Press.

Committee on Assessing Integrity in Research Environments National Research Council \& Institute of Medicine. 2002. Integrity in scientific research: creating an environment that promotes responsible conduct. Washington, D.C.: The National Academies Press.

Connell, Hellen. 2004. University research management: Meeting the institutional challenge. Paris: OECD Publishing.

Dao, Khanh Van. 2014. Key challenges in the reform of governance, quality assurance, and finance in Vietnamese higher education - a case study. Studies in Higher Education 40(5): 745-760. doi:10.1080/03075079.2013.842223. 
Edgar, Fiona, and Alan Geare. 2013. Factors influencing university research performance. Studies in Higher Education 38(5): 774-792.

Frankel, Mark S., and Jane Cave. 1997. Evaluating science and scientists: An east-west dialogue on research evaluation in post-communist Europe. Budapest: Central European University Press.

Ha, Thanh. 2009. 400 triệu USD xây dựng bốn trường ĐH "trình độ quốc tế" (400 million USD for building four world-class universities).

Hansson, F. 2008. Research leadership as entrepreneurial organizing for research. Higher Education 55(6):651.

Harris, Michael. 2010. Interdisciplinary strategy and collaboration: A case study of American Research Universities. Journal of Research Administration 41(1): 22-34.

Hien, P. D. 2010. A comparative study of research capabilities of East Asian countries and implications for Vietnam. Higher Education 60(6): 615-625.

Kirkland, John. 2008. University research management: An emerging profession in the developing world. Technology Analysis and Strategic Management 20(6): 717-726.

Liu, Nian Cai, Qi Wang, and Ying Cheng. 2011. Paths to a world-class university: Lessons from practices and experiences. Rotterdam: Sense Publishers.

Ly, Pham Thi. 2013. Case study: the effectiveness of research and innovation management at policy and institutional levels in Vietnam. In Effectiveness of research and innovation management at policy and institutional levels: Cambodia, Malaysia, Thailand and Vietnam, eds. Åsa Olsson, and Lynn Meek, 140-162. OECD.

Marginson, Simon. 2014. University Rankings and Social Science. European Journal of Education 49 (1):45-59. doi:10.1111/ejed.12061.

McNay, I. 2010. Research quality assessment. In International Encyclopedia of Education, eds. Penelope Peterson, Eva Baker, and Barry McGaw. Oxford: Elsevier.

Meek, V. Lynn, and Dianne Davies. 2009. Policy Dynamics in Higher Education and Research: Concepts and Observations. In Higher Education, Research, and Innovation: Changing Dynamics - Report on the UNESCO Forum on Higher Education, Research and Knowledge 2001 - 2009, eds. V. Lynn Meek, Ulrich Teichler, and Mary Louise Kearney, 41-82. Kassel: International Centre for Higher Education Research Kassel.

Mintzberg, H. 1973. The nature of managerial work. New York: Harper \& Row.

Mintzberg, Henry. 1979. The structuring of organizations: a synthesis of the research. Englewood Cliffs, N.J.: Prentice-Hall.

Moed, Henk F., W. J. M. Burger, J. G. Frankfort, and Anthony F. J. Van Raan. 1985. The use of bibliometric data for the measurement of university research performance. Research Policy 14(3):131-149. doi:10.1016/0048-7333(85)90012-5.

National Academy of Sciences. 1995. On being a scientist: Responsible conduct in research. Washington, DC: National Academy Press.

Ngo, Mai Tuyet. 2014. "A quest for a new model of public university governance that promotes incentives for academic excellence for modern Vietnam: Lessons from multi-site comparative case studies in East Asia." PhD Thesis, Faculty of Arts \& Social Science, The University of New South Wales.

Nguyễn, Hương Thi Lan. 2014. Research in universities. In Higher education in Vietnam: flexibility, mobility and practicality in the global knowledge economy, eds. Lý Trần, Simon Marginson, Hoàng Đỗ, Quyên Đỗ, Trúc Lê, Nhài Nguyễn, Thảo Vũ, Thạch Phạm, and Hương Nguyễn. New York: Palgrave Macmillan. 
Nguyen, Thi Lan Huong. 2013. "Building university research capacity in Vietnam: Prospects, problems, and possibilities." PhD Thesis, Melbourne Graduate School of Education, The University of Melbourne.

Nguyen, Thi Lan Huong. 2013a. The challenges of developing research resources at leading Vietnamese universities. Higher Education Management and Policy 24(2): 115-130.

Nguyen, Thi Lan Huong. 2013b. Middle-level academic management: A case study on the roles of the heads of department at a Vietnamese university. Tertiary Education and Management 19(1): $1-15$.

Nguyen, Thi Lan Huong. 2015. "Building human resources management capacity for university research: The case at four leading Vietnamese universities." Higher Education: 1-21. doi: 10.1007/s10734-015-9898-2.

Nguyen, Thi Lan Huong, and Vincent Lynn Meek. 2015. Key considerations in organizing and structuring university research. The Journal of Research Administration 46(1): 41-62.

Nguyen, Tuan V., and Ly T. Pham. 2011. Scientific output and its relationship to knowledge economy: an analysis of ASEAN countries. Scientometrics 89(1): 107-117. doi:10.1007/s11192-011-0446-2.

OECD. 1996. The Knowledge-based economy. Paris: OECD.

OECD. 2005. University research management: developing research in new institutions. OECD Publishing.

Olsson, Åsa, and Lynn Meek (eds.). 2013. Effectiveness of research and innovation management at policy and institutional levels: Cambodia, Malaysia, Thailand and Vietnam. Paris: OECD.

Paul, R. J. 2008. Measuring research quality: the United Kingdom Government's Research Assessment Exercise. European Journal of Information Systems 17(4): 324-329. doi:10.1057/ejis.2008.31.

Pettigrew, Alan, Molly Lee, Lynn Meek, and Fabiana Barros de Barros. 2013. A typology of knowledge and skills requirements for effective research and innovation management. In Effectiveness of research and innovation management at policy and institutional levels: Cambodia, Malaysia, Thailand and Vietnam, eds. Åsa Olsson, and Lynn Meek, 29-74. Paris: OECD Publishing.

Quốc hội. 2010. Luật Viên chức, luật số 58/2010/QH12, ban hành ngày 15/11/2010 (Law for employees working in state-owned organizations, rule number 58/2010/QH12, issued on $15 / 11 / 2010)$.

Quốc hội. 2012. Luật Giáo dục Đại học, số hiệu 08/2012/QH13, ban hành ngày 18/6/2012 (Higher Education Law, rule number 08/2012/QH13, issued on 18/6/2012).

Salmi, Jamil. 2009. The challenge of establishing world-class universities. Washington DC: World Bank.

Schermerhorn, J. R., P. Davidson, D. Poole, A. Simon, P. Woods, and S. L. Chau. 2011. Management: foundations and applications (Australian edition). Milton, QLD: John Wiley \& Sons.

Schermerhorn, J. R., P. Davidson, D. Poole, A. Simon, P. Woods, and S. L. Chau. 2011. Management: 4th Asia-Pacific edition. Milton, QLD: John Wiley \& Sons.

Steneck, Nicholas H. 2007. ORI introduction to the responsible conduct of research. Washington, DC: U.S. Government Printing Office.

Taylor, Jim. 2011. The assessment of research quality in UK Universities: Peer review or metrics? British Journal of Management 22(2): 202-217. doi:10.1111/j.1467-8551.2010.00722.x.

Taylor, John. 2006. Managing the unmanageable: The management of research in research-intensive universities. Higher Education Management \& Policy 18(2): 1-25. 
Thoenig, Jean-Claude, and Catherine Paradeise. 2014. Organizational governance and the production of academic quality: Lessons from two top U.S. research universities. Minerva 52(4): 381417.

Thủ tướng chính phủ. 2007. Quyết định số 121/2007/QĐ-TTg của Thủ tướng Chính phủ phê duyệt quy hoạch mạng lưới các trường đại học và cao đẳng giai đoạn 2006 - 2020 (Decision number 121/2007/QD-TTg of the Prime Minister approving the plan for developing the national network of universities and colleges for the period 2006-2020): The Vietnamese Government.

Thủ tướng Chính phủ. 2010. Quyết định số 58/2010/QĐ-TTg, 22/9/2010, Điều lệ trường đại học (Decision number 58/2010/QĐ-TTg, 22/9/2010, University Regulations), ed. Goverment Office. Vietnam: 58/2010/QĐ-TTg.

Thủ tướng Chính phủ. 2011. Quyết định Phê duyệt Đề án hội nhập quốc tế về khoa học và công nghệ đến năm 2020, số 735/QĐ-TTg, ngày 18/5/2011 (Decision on approving the project of international integration in science and technology to 2020, decision number 735/QĐ-TTg, issued on 18/5/2011).

Thủ tướng Chính phủ. 2014a. Công văn số 821/TTg-KGVX V/v chủ trương đầu tư Dự án thành lập Trường Đại học Fulbright Việt Nam tại Thành phố Hồ Chí Minh, ngày 03/06/2014 (Document numbered 821/TTg-KGVX to approve in principle the establishment of Fulbright University Vietnam in Ho Chi Minh city, dated 03/06/2014).

Thủ tướng Chính phủ. 2014b. Quyết định về việc thành lập Trường Đại học Việt Nhật thuộc Đại học Quốc Gia Hà nội số 1186/QĐ-TTg ngày 21/07/2014 (Decision to establish Vietnamese Japanese university which belongs to Vietnam National University, Hanoi, decision number 1186/QĐ-TTg dated 21/07/2014).

Tran, Thi Tuyet. 2014. Governance in higher education in Vietnam - a move towards decentralization and its practical problems. Journal of Asian Public Policy 7(1): 71-82. doi:10.1080/17516234.2013.873341.

UN Millennium Project. 2003. Background Paper of the Task Force on Science, Technology and Innovation.

Woelert, Peter. 2015. Governing Knowledge: The Formalization Dilemma in the Governance of the Public Sciences. Minerva 53(1): 1-19. doi:10.1007/s11024-015-9266-5.

World Bank. 1998/99. Knowledge for development. World Development Report. Washington DC.

Yin, R. K. 2009. Case study research: Design and methods (4th ed.). Thousand Oaks, CA: Sage.

\begin{tabular}{|c|c|c|c|c|c|c|c|c|c|c|c|c|}
\hline University & Students & Academics & \begin{tabular}{|c|} 
Student \\
Teacher \\
Ratio \\
\end{tabular} & $\begin{array}{c}\text { Professors/A } \\
\text {.Professors }\end{array}$ & $\begin{array}{l}\text { Academics } \\
\text { with a PhD }\end{array}$ & $\begin{array}{c}\text { Academics } \\
\text { with a } \\
\text { Masters }\end{array}$ & \begin{tabular}{|l|} 
National \\
research \\
projects \\
\end{tabular} & \begin{tabular}{|l|} 
Ministry \\
research \\
projects \\
\end{tabular} & $\begin{array}{c}\text { Institutional } \\
\text { research } \\
\text { projects }\end{array}$ & $\begin{array}{c}\text { Domestic } \\
\text { research } \\
\text { publications }\end{array}$ & \begin{tabular}{|c|} 
International \\
research \\
publications
\end{tabular} & $\begin{array}{c}\text { Academic } \\
\text { year }\end{array}$ \\
\hline $\begin{array}{l}\text { The natural } \\
\text { sciences }\end{array}$ & 4,800 & 358 & 13,4 & $31 \%$ & $69 \%$ & $26 \%$ & 28 & 167 & 125 & 321 & 205 & 2011-2012 \\
\hline The engineering & 42,000 & 1,266 & 33 & $14 \%$ & $47 \%$ & $45 \%$ & 48 & 189 & 246 & 300 & 100 & 2010-2011 \\
\hline The economics & 45,000 & 759 & 59 & $15 \%$ & $34 \%$ & $52 \%$ & 5 & 15 & 50 & $\mathrm{n} / \mathrm{a}$ & 30 & 2011-2012 \\
\hline $\begin{array}{l}\text { The medical } \\
\text { sciences }\end{array}$ & 5,000 & 255 & 20 & $60 \%$ & $80 \%$ & $20 \%$ & $\mathrm{n} / \mathrm{a}$ & $\mathrm{n} / \mathrm{a}$ & $\mathrm{n} / \mathrm{a}$ & $\mathrm{n} / \mathrm{a}$ & $\mathrm{n} / \mathrm{a}$ & 2011-2012 \\
\hline
\end{tabular}




\begin{tabular}{|c|c|c|}
\hline \multirow{5}{*}{$\begin{array}{c}\text { More } \\
\text { visible } \\
\text { tasks }\end{array}$} & 11. Create research positions & 2 \\
\hline & 12. Create research management positions & 2 \\
\hline & 13. Decide primary organizational units for research delivery & 2 \\
\hline & 14. Create a research office & 2 \\
\hline & 15. Create research oversight committees & 3 \\
\hline \multirow{5}{*}{$\begin{array}{c}\text { Less } \\
\text { visible } \\
\text { tasks }\end{array}$} & 16. Develop rules for research integrity & 1 \\
\hline & $\begin{array}{l}\text { 17. Develop rules and procedures for managing the lifecycle of } \\
\text { a research project }\end{array}$ & 2 \\
\hline & $\begin{array}{l}\text { 18. Develop a mechanism for evaluating the quality of research } \\
\text { outcomes }\end{array}$ & 1 \\
\hline & $\begin{array}{l}\text { 19. Prepare researchers and research managers for necessary } \\
\text { skills and knowledge }\end{array}$ & 1 \\
\hline & 20. Decide vertical and horizontal decentralization & 1 \\
\hline
\end{tabular}




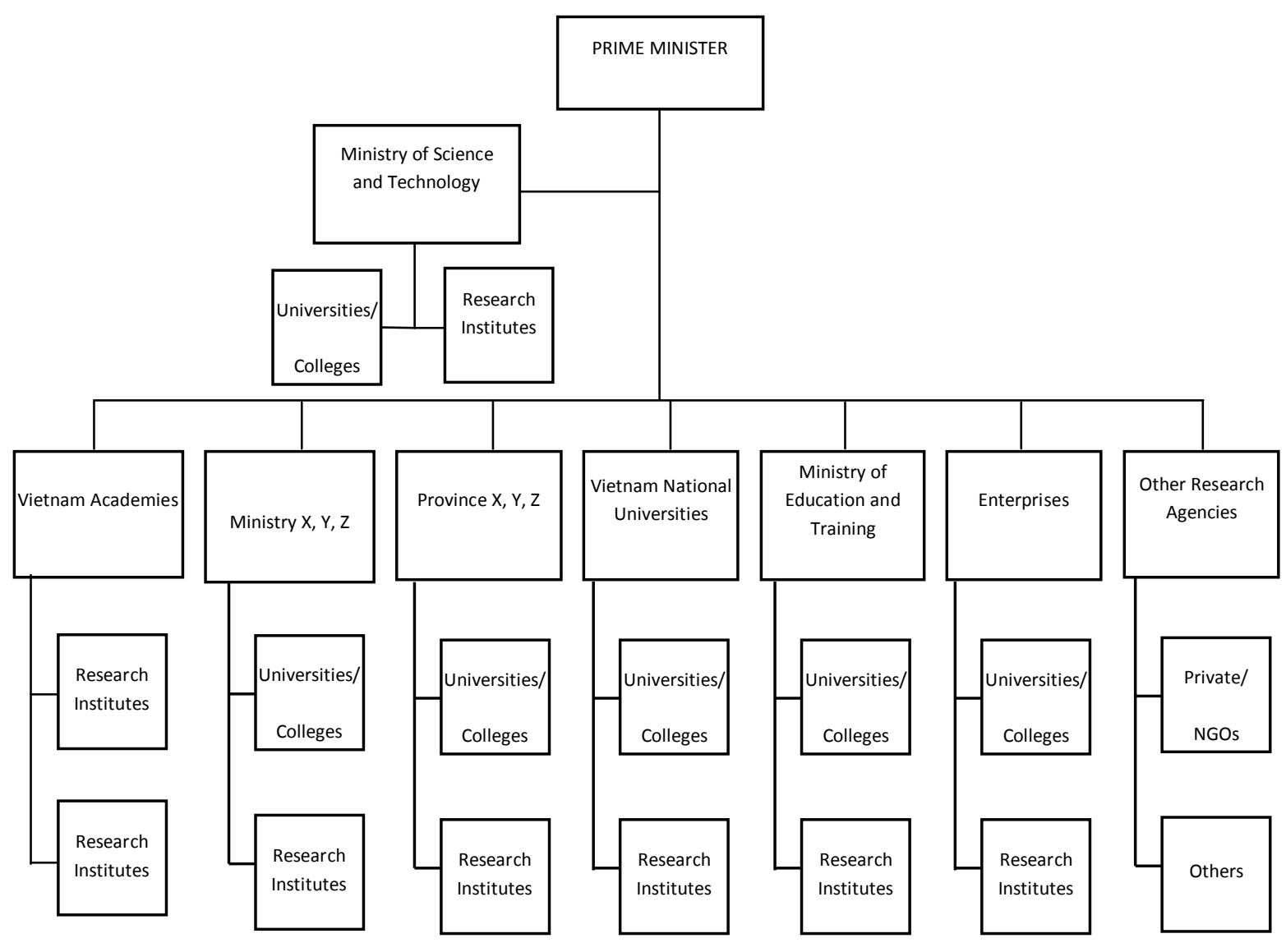



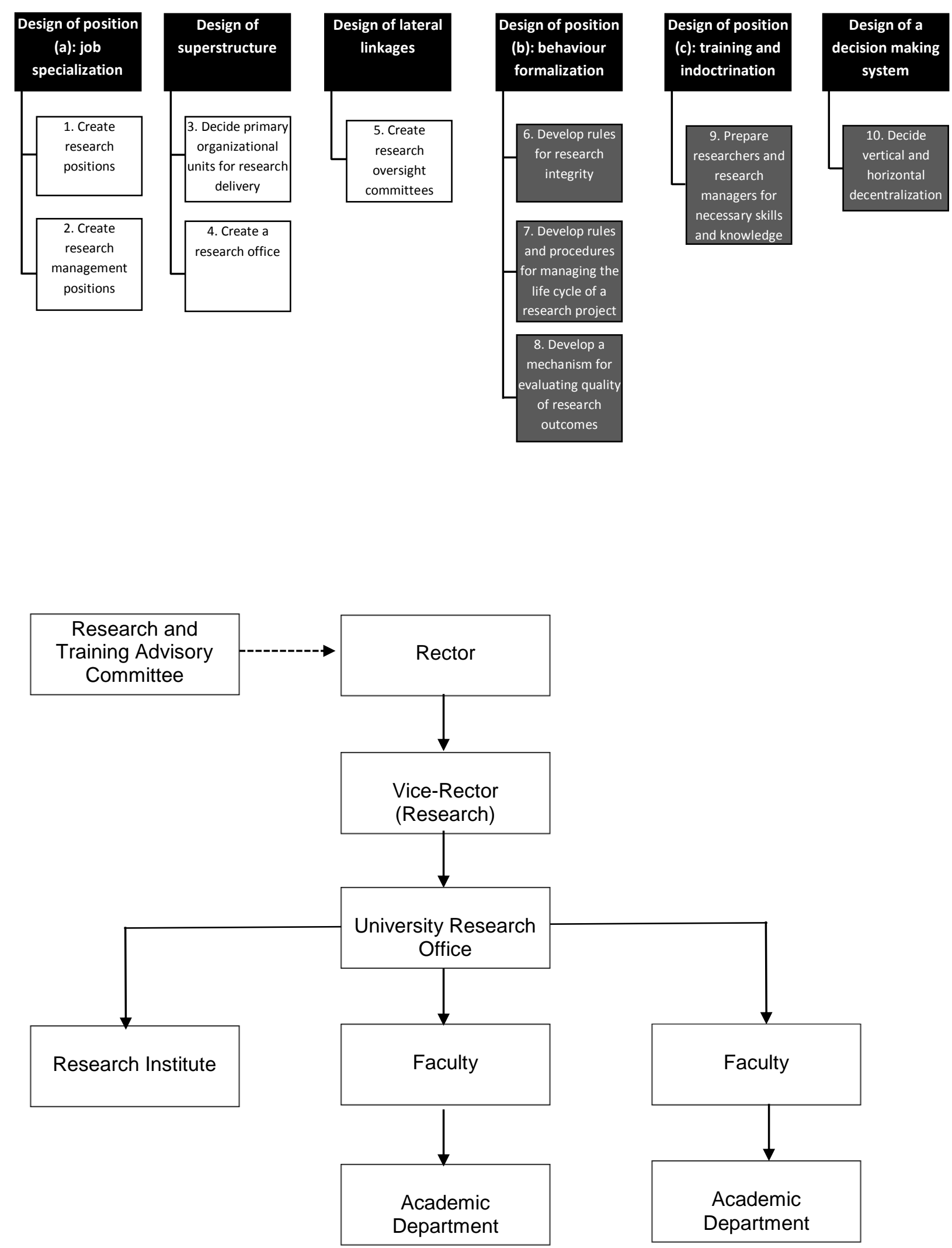


\section{University Library}

\section{- M M N E R VA A gateway to Melbourne's research publications}

Minerva Access is the Institutional Repository of The University of Melbourne

Author/s:

Huong, TLN;Meek, VL

Title:

Key Problems in Organizing and Structuring University Research in Vietnam: The Lack of an Effective Research "Behaviour Formalization" System

Date:

2016-03-01

Citation:

Huong, T. L. N. \& Meek, V. L. (2016). Key Problems in Organizing and Structuring University Research in Vietnam: The Lack of an Effective Research "Behaviour Formalization" System. MINERVA, 54 (1), pp.45-73. https://doi.org/10.1007/s11024-016-9289-6.

Persistent Link:

http://hdl.handle.net/11343/282942 